\title{
Mimicking Peroxidase Activity by a Manganese(II) Complex Involving a New Asymmetric Tetradentate Ligand Containing Both Amino and Imino Groups
}

\author{
Yolanda Pérez-Otero, M. Isabel Fernández-García, Esther Gómez-Fórneas, \\ Gustavo González-Riopedre, and Marcelino Maneiro \\ Departamento de Química Inorgánica, Facultad de Ciencias, Universidade de Santiago de Compostela, 27002 Lugo, Spain \\ Correspondence should be addressed to Marcelino Maneiro; marcelino.maneiro@usc.es
}

Received 30 September 2015; Accepted 8 December 2015

Academic Editor: Henryk Kozlowski

Copyright ( $) 2015$ Yolanda Pérez-Otero et al. This is an open access article distributed under the Creative Commons Attribution License, which permits unrestricted use, distribution, and reproduction in any medium, provided the original work is properly cited.

\begin{abstract}
The asymmetric ligand (E)-4-bromo-2-(((2-((5-bromo-2-hydroxybenzyl)(methyl)amino)ethyl)imino)methyl)phenol has been prepared by a novel seven-step route. All organic compounds isolated in each step have been characterised by elemental analysis, infrared and ${ }^{1} \mathrm{H}$ NMR spectroscopy, and mass spectrometry. Interaction of this ligand with manganese has been investigated employing an electrochemical method. This method leads to the formation of a neutral manganese(II) complex 7 in high yield and purity. The complex has been thoroughly characterised by elemental analysis, infrared spectroscopy, mass spectrometry, magnetic susceptibility measurements, and cyclic voltammetry. Complex 7 behaves as peroxidase mimic in the presence of the water-soluble trap ABTS, probably due to its ease to coordinate the substrate molecule.
\end{abstract}

Dedicated to Professor Manuel R. Bermejo on the occasion of his 70th birthday

\section{Introduction}

Oxidative stress causes uncontrolled oxidation of organic molecules with secondary alteration of their structure and biological functions, leading to the progressive deterioration and the collapse of organs and systems in the living organisms [1-3]. The superoxide dismutase, catalase, and peroxidase enzymes are part of the defense mechanisms against the reactive oxygen species generated by oxidative stress [4-7].

Vast interest has been developed to devise small molecule models, the properties of which can be compared with different metalloproteins [8-11]. Biomimetic modeling of metal complexes has denoted a better catalytic behaviour when the complex is able to easily coordinate the substrate molecule, and this is favoured when the catalyst has either a vacancy in the coordination sphere or a labile ligand [12-15]. To achieve this, a careful design of the ligand is necessary. In this connection, unsymmetrical ligands are also required to imitate many of the active sites of the metalloproteins [16-18].

Tetradentate ONNO Schiff bases are well-known systems for coordination of metal ions, and their synthesis is easily accomplished by condensation of salicylaldehyde and diamines [19, 20]. However, this condensation favours symmetrization processes, and symmetric ligands are systematically obtained even using a mixture of different salicylaldehydes in solution [21]. Consequently, alternative synthetic routes should be explored to achieve unequivocally unsymmetrical ligands.

We report here on the synthesis of a new type of unsymmetrical ONNO tetradentate imino-amino bishydroxy ligand following a novel seven-step synthetic route. The ability of the new ligand to coordinate a redox-active metal ion as manganese is checked by an electrochemical synthesis procedure. Finally, catalytic studies to determine the peroxidase 
activity have been carried out using the obtained manganese compound.

\section{Materials and Methods}

2.1. Materials. All the starting materials (Aldrich) and solvents (Probus) used for the synthesis were of commercially available reagent grade and were used without further purification.

2.2. Physical Measurements. Elemental analyses were performed on a Carlo Erba Model 1108 CHNS-O elemental analyser. The IR spectra were recorded on $\mathrm{KBr}$ pellets on a Bio-Rad FTS 135 spectrophotometer in the range 4000$400 \mathrm{~cm}^{-1}$. ${ }^{1} \mathrm{H}$ spectra were recorded on a Bruker AC300 spectrometer using DMSO- $\mathrm{d}_{6}(296 \mathrm{~K})$ as solvent and $\mathrm{SiMe}_{4}$ as an internal reference. FAB mass spectra were recorded on a Kratos MS50TC spectrometer connected to a DS90 data system, using meta-nitrobenzyl alcohol as a matrix. Electrospray ionization mass spectra of the compounds were obtained on a Hewlett-Packard model LCMSD 1100 instrument (positive-ion mode, $98: 2 \mathrm{CH}_{3} \mathrm{OH} /$ $\mathrm{HCOOH}$ as the mobile phase, $30-100 \mathrm{~V}$ ). Room-temperature magnetic susceptibilities were measured using a digital measurement system MSB-MKI, calibrated using mercury tetrakis(isothiocyanato)cobaltate(II), $\mathrm{Hg}\left[\mathrm{Co}(\mathrm{NCS})_{4}\right]$, as a susceptibility standard. Magnetic data for 7 at different applied field strengths was obtained with a Quantum Design PPMS susceptometer. Conductivities of $10^{-3} \mathrm{M}$ solutions in DMF were measured on a Crison microCM 2200 conductivimeter.

Cyclic voltammetry was performed using an EG\&G PAR model 273 potentiostat, controlled by EG\&G PAR model 270 software. A Metrohm model 6.1204.000 graphite disc coupled to a Metrohm model 628-10 rotating electrolyte device was used as a working electrode. A saturated calomel electrode was used as a reference and a platinum wire as an auxiliary electrode. All measurements were made with ca. $10^{-3} \mathrm{~mol} \mathrm{dm}^{-3}$ solutions of the complexes in dimethylformamide using $0.2 \mathrm{~mol} \mathrm{dm}^{-3} \mathrm{NBu}_{4} \mathrm{PF}_{6}$ as a supporting electrode. Cyclic voltammetry measurements were performed with a static graphite electrode.

2.3. Preparation of the Organic Ligand. The asymmetrical ligand (E)-4-bromo-2-(((2-((5-bromo-2-hydroxybenzyl)(methyl)amino)ethyl)imino)methyl)phenol $\left(\mathbf{H}_{2} \mathbf{L}^{\mathbf{1}}\right)$ has been successfully obtained by means of a seven-step synthetic route (see Scheme 1).

Phthalimido-acetal (1). Potassium phthalimide (5 g, $26.5 \mathrm{mmol})$, bromoacetal $(4.1 \mathrm{~mL}, 26.5 \mathrm{mmol})$, and hexadecyltributylphosphonium bromide $(13.8 \mathrm{~g}, 26.5 \mathrm{mmol})$ were heated together in toluene $(200 \mathrm{~mL})$ for $24 \mathrm{~h}$ at $111^{\circ} \mathrm{C}$ under $\mathrm{N}_{2}$ atmosphere. The product was then filtered, and the filtrate was concentrated on a rotary evaporator to give yellow oil. Column chromatography using hexane : ether $(1: 1)$ allowed obtaining the desired compound. Yield 70\%; Elemental analysis calculated for $\mathrm{C}_{14} \mathrm{H}_{17} \mathrm{NO}_{4}$ (263.29): $\mathrm{C}$ 63.8, $\mathrm{H} \mathrm{6.4}$,
$\mathrm{N}$ 5.3; found: C 64.6, H 6.5, N 5.3. ${ }^{1} \mathrm{H}$ NMR (300 MHz, $\left.\mathrm{CDCl}_{3}\right): \delta 7.8-7.6(\mathrm{~m}, 4 \mathrm{H}), 4.79(\mathrm{t}, 1 \mathrm{H}), 3.75(\mathrm{~d}, 2 \mathrm{H}), 3.62-$ $3.42(\mathrm{~m}, 4 \mathrm{H}), 1.06(\mathrm{t}, 6 \mathrm{H})$. ES-MS: $m / z$ 264. IR: $\nu(\mathrm{C}-\mathrm{O}-\mathrm{C})$ 2800, $\nu(\mathrm{C}=\mathrm{O}) 1721 \mathrm{~cm}^{-1}$.

Phthalimidoacetaldehyde (2). The foregoing compound ( $3 \mathrm{~g}$ ) and hydrochloric acid $(15 \mathrm{~mL})$ were heated at $100^{\circ} \mathrm{C}$ for 30 minutes with stirring. The product crystallised on cooling. It was collected and purified from diethyl ether. Yield 80\%; Elemental analysis calculated for $\mathrm{C}_{10} \mathrm{H}_{7} \mathrm{NO}_{3}$ (189.17): C 63.4, H 3.7, N 7.4; found: C 62.4, H 3.4, N 7.5. ${ }^{1} \mathrm{H}$ NMR $(300 \mathrm{MHz}$, $\left.\mathrm{CDCl}_{3}\right): \delta 9.62(\mathrm{~s}, 1 \mathrm{H}), 7.85-7.65(\mathrm{~m}, 4 \mathrm{H}), 4.45(\mathrm{~s}, 2 \mathrm{H})$. ES-MS: $m / z$ 190. IR: $\nu(\mathrm{C}=\mathrm{O}) 1721 \mathrm{~cm}^{-1}$.

4-Bromo-2-((methylamino)methyl)phenol (3). To an ethanolic solution $(100 \mathrm{~mL})$ of 4-bromo-salicylaldehyde $(5 \mathrm{~mL}$, $46.7 \mathrm{mmol})$, methylamine $(8.06 \mathrm{~mL}, 93.4 \mathrm{mmol})$ was added. The mixture was heated under reflux in a round-bottom flask fitted with a Dean-Stark trap to remove the water produced during the reaction. After heating for $3 \mathrm{~h}$, the solution is left at room temperature and then sodium borohydride $(0.90 \mathrm{~g}, 23.3 \mathrm{mmol})$ was added. The solution was stirred for $2 \mathrm{~h}$ before adding a second fraction of sodium borohydride $(0.90 \mathrm{~g}, 23.3 \mathrm{mmol})$. After stirring for $2 \mathrm{~h}$, the solution was cooled in an ice bath and acidified to $\mathrm{pH}$ 2. The solvent was evaporated and the residue was extracted with distilled water/diethyl ether $(3 \times 20 \mathrm{~mL})$. The combined aqueous phases were adjusted to $\mathrm{pH} 11$ by addition of aqueous potassium hydroxide and extracted with dichloromethane $(3 \times 30 \mathrm{~mL})$. The combined organic phases were dried with anhydrous sodium sulphate, and the solvent was evaporated. The solid was dried in vacuo. Yield 35\%; Elemental analysis calculated for $\mathrm{C}_{8} \mathrm{H}_{10} \mathrm{BrNO}$ (263.29): $\mathrm{C} 44.4, \mathrm{H} 4.6, \mathrm{~N} 6.5$; found: $\mathrm{C} 44.2, \mathrm{H} 4.4, \mathrm{~N} 6.5 .{ }^{1} \mathrm{H}$ NMR $\left(300 \mathrm{MHz}, \mathrm{CDCl}_{3}\right): \delta$ 7.19-6.63 (m, 3H), 4.8-4.2 (a, 1H), $3.86(\mathrm{~s}, 2 \mathrm{H}), 2.40(\mathrm{~s}, 3 \mathrm{H})$. ES-MS: $m / z$ 264. IR: $v(\mathrm{O}-\mathrm{H}) 3014, v(\mathrm{~N}-\mathrm{H}) 2736 \mathrm{~cm}^{-1}$.

2-((6-Bromo-3-methyl-3,4-dihydro-2H-benzo[e][1,3]oxazin2-yl)methyl)isoindoline-1,3-dione (4). A $100 \mathrm{~mL}$ Schlenk flask was charged under $\mathrm{N}_{2}$ with a solution of $0.72 \mathrm{~g}$ $(3.33 \mathrm{mmol})$ of salicylamine 3 in THF. Under $\mathrm{N}_{2}$ stream, phthalimidoacetaldehyde 2 was added $(0.95 \mathrm{~g}, 5.03 \mathrm{mmol})$. The flask, saturated with $\mathrm{N}_{2}$, is left to stir for $20 \mathrm{~h}$ at room temperature. Then, a white product was collected by filtration, washed with diethyl ether, and dried in air. Yield 65\%; Elemental analysis calculated for $\mathrm{C}_{18} \mathrm{H}_{15} \mathrm{BrN}_{2} \mathrm{O}_{3}$ (387.22): C 55.9, H 3.9, N 7.2; found: C 55.0, H 4.2, N 7.4. ${ }^{1} \mathrm{H}$ NMR $\left(300 \mathrm{MHz}, \mathrm{CDCl}_{3}\right): \delta 7.90-7.71(\mathrm{~m}, 4 \mathrm{H}), 7.26-6.64(\mathrm{~m}$, $3 \mathrm{H}), 5.14(\mathrm{t}, 1 \mathrm{H}), 4.08-3.95(\mathrm{~m}, 4 \mathrm{H}), 2.51(\mathrm{~s}, 3 \mathrm{H}) . \mathrm{IR}: \nu(\mathrm{C}=\mathrm{O})$ $1719 \mathrm{~cm}^{-1}$.

2-(2-((5-Bromo-2-hydroxybenzyl)(methyl)amino)ethyl) isoindoline-1,3-dione (5). Benzoxazine $4(2 \mathrm{~g}, 5.17 \mathrm{mmol})$ was stirred in a mixture of dichloromethane $(25 \mathrm{~mL})$ and acetonitrile $(20 \mathrm{~mL})$. Sodium cyanoborohydride $(0.43 \mathrm{~g}, 6.46 \mathrm{mmol}$, $1.25 \mathrm{eq})$ was added and the mixture was acidified with hydrochloric acid to $\mathrm{pH}$ of ca. 2. After $6 \mathrm{~h}$, the mixture was acidified with hydrochloric acid to $\mathrm{pH}$ ca. 1 . After $1 \mathrm{~h}$ of stirring, the solvent was removed. The residue 
was dried in vacuo and extracted with a 9:1 mixture of dichloromethane/methanol (saturated with ammonia). The solvent was evaporated and the residue again vacuumdried. Recrystallization of the crude product from absolute methanol afforded the desired product. Yield 70\%; Elemental analysis calculated for $\mathrm{C}_{18} \mathrm{H}_{17} \mathrm{BrNO}_{3}$ (389.24): $\mathrm{C}$ 55.5, $\mathrm{H} \mathrm{4.4}$, $\mathrm{N}$ 7.2; found: C 55.6, H 4.9, N 7.6. ${ }^{1} \mathrm{H}$ NMR $(300 \mathrm{MHz}$, DMSO): $\delta 7.89-7.80(\mathrm{~m}, 4 \mathrm{H}), 7.19(\mathrm{~d}, 2 \mathrm{H}), 6.49(\mathrm{~d}, 1 \mathrm{H}), 3.77$ $(\mathrm{t}, 2 \mathrm{H}), 3.60(\mathrm{~s}, 2 \mathrm{H}), 2.70(\mathrm{~s}, 2 \mathrm{H}), 2.30(\mathrm{~s}, 3 \mathrm{H}) . \mathrm{IR}: \nu(\mathrm{C}=\mathrm{O})$ $1709 \mathrm{~cm}^{-1}$.

2-(((2-Aminoethyl)(methyl)amino)methyl)-4-bromophenol (6). Under nitrogen, a $100 \mathrm{~mL}$ round-bottom flask was charged with a solution of $0.31 \mathrm{~g}(0.79 \mathrm{mmol})$ of 5 in $10 \mathrm{~mL}$ of absolute tetrahydrofuran and $10 \mathrm{~mL}$ of absolute ethanol. Hydrazine hydrate ( $99 \%, 0.26 \mathrm{~mL}, 5 \mathrm{mmol}$ ) was added. After stirring at room temperature for $24 \mathrm{~h}$, the reaction mixture was acidified with concentrated hydrochloric acid to $\mathrm{pH}$ of ca. 1 and stirred for another $10 \mathrm{~min}$. The solvent was evaporated, and the residue was extracted with water $(3 \times$ $20 \mathrm{~mL}$ ). The combined aqueous phases were adjusted to $\mathrm{pH} 11$ by addition of anhydrous potassium hydroxide and extracted with dichloromethane $(3 \times 30 \mathrm{~mL})$. The combined organic phases were dried with anhydrous sodium sulphate, and the solvent was evaporated. The solid residue was washed with diethyl ether and then dried in vacuo. Yield 45\%; Elemental analysis calculated for $\mathrm{C}_{10} \mathrm{H}_{15} \mathrm{BrN}_{2} \mathrm{O}$ (389.24): $\mathrm{C} 46.3, \mathrm{H}$ 5.8, N 10.8; found: C 47.3, H 5.6, N 10.1. ${ }^{1} \mathrm{H}$ NMR $(300 \mathrm{MHz}$, DMSO): $\delta 7.21-6.62(\mathrm{~m}, 3 \mathrm{H}), 4.1-3.7(\mathrm{a}, 2 \mathrm{H}), 3.59(\mathrm{~s}, 2 \mathrm{H})$, $2.84(\mathrm{t}, 2 \mathrm{H}), 2.49$ (t, $2 \mathrm{H}), 2.23$ (s, 3H). ES-MS: $m / z$ 390. IR: $v(\mathrm{O}-\mathrm{H}) 3473, v(\mathrm{~N}-\mathrm{H}) 3280 \mathrm{~cm}^{-1}$.

(E)-4-Bromo-2-(((2-((5-bromo-2-hydroxybenzyl)(methyl)amino)ethyl)imino)methyl)phenol $\left(\boldsymbol{H}_{2} \boldsymbol{L}^{\mathbf{1}}\right)$. To a solution of primary amine $6(0.105 \mathrm{~g}, 0.405 \mathrm{mmol})$ in chloroform, 4-bromo-salicylaldehyde $(0.081 \mathrm{~g}, 0.405 \mathrm{mmol})$ was added. The mixture was heated under reflux in a round-bottom flask fitted with a Dean-Stark trap to remove the water produced during the reaction. After heating for $3 \mathrm{~h}$, the solution was concentrated to yield a yellow solid. The product was collected by filtration, washed with diethyl ether, and dried in air. Yield $85 \%$; Elemental analysis calculated for $\mathrm{C}_{17} \mathrm{H}_{18} \mathrm{Br}_{2} \mathrm{~N}_{2} \mathrm{O}_{2}$ (442.14): C 46.1, H 4.1, N 6.3; found: C 46.4, $\mathrm{H} 4.1, \mathrm{~N}$ 6.3. ${ }^{1} \mathrm{H}$ NMR $(300 \mathrm{MHz}, \mathrm{DMSO}): \delta 8.12(\mathrm{~s}, 1 \mathrm{H})$, 7.34-6.60 (m, 6H), $3.71(\mathrm{t}, 2 \mathrm{H}), 3.65(\mathrm{~s}, 2 \mathrm{H}), 2.78(\mathrm{t}, 2 \mathrm{H})$, 2.29 (s, 3H). ES-MS: $m / z$ 443. IR: $v(\mathrm{C}=\mathrm{N}) 1634 \mathrm{~cm}^{-1} ; \nu(\mathrm{C}-\mathrm{O})$ $1270 \mathrm{~cm}^{-1}$.

2.4. Complex Preparation. $\left[\mathrm{MnL} \mathrm{L}^{1}\left(\mathrm{OH}_{2}\right)_{2}\right] \cdot \mathrm{H}_{2} \mathrm{O}$ (7) was obtained following an electrochemical procedure (see Figure 1). The cell was a beaker $\left(100 \mathrm{~cm}^{3}\right)$ fitted with a rubber bung, through which the electrochemical leads entered the cell [22]. A manganese metal platelet was suspended from a platinum wire and a platinum wire was used as a cathode. The ligand $\mathbf{H}_{2} \mathbf{L}^{1}(0.1 \mathrm{~g})$ was dissolved in acetonitrile $\left(70 \mathrm{~cm}^{3}\right)$ and a small amount of tetramethylammonium perchlorate was added as a supporting electrolyte. During electrolysis, nitrogen was bubbled through the solution

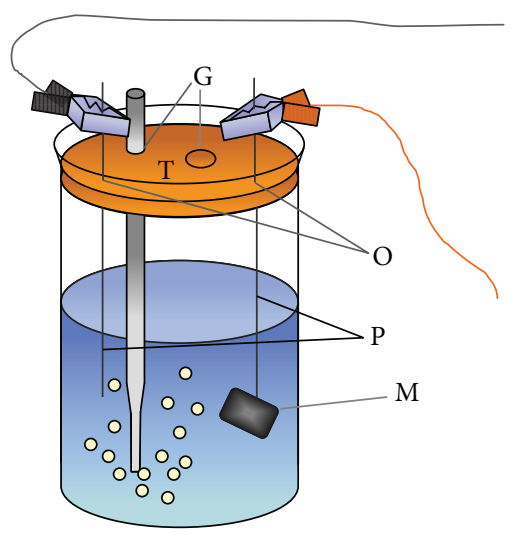

FIGURE 1: Scheme of electrochemical cell. T: rubber stopper; G: inert gas entry/exit; P: platinum cathode; M: manganese anode.

to ensure the presence of an inert atmosphere, with the current being provided by a purpose built DC power supply. The cells can be summarized as follows: $\mathrm{Pt}(-) / \mathrm{MeCN}+$ $\mathbf{H}_{2} \mathrm{~L}^{n} / \mathrm{Mn}(+)$. During electrolysis, hydrogen gas was evolved at the cathode. The solid was collected by filtration and washed successively with acetonitrile and diethyl ether before drying in vacuo. Yield: $75 \%$. Elemental analysis calculated for $\mathrm{C}_{17} \mathrm{H}_{22} \mathrm{MnBr}_{2} \mathrm{~N}_{2} \mathrm{O}_{5}$ (549.11): C 37.2, $\mathrm{H} \mathrm{4.0,N}$ 5.1; found: C 36.9, H 4.3, N 5.2. FAB: $m / z 494.9[\mathrm{MnL}]^{+}$. IR: $\nu(\mathrm{C}=\mathrm{N}) 1627 \mathrm{~cm}^{-1} \cdot \nu(\mathrm{C}-\mathrm{O}) 1273 \mathrm{~cm}^{-1} \cdot \mu=5.94 \mathrm{~B}$. M. Conductivity (in DMF) $\Lambda_{M}=9 \mu \mathrm{S} . E_{\mathrm{ox}}=0.488 \mathrm{~V}$. $E_{\text {red }}=0.150 \mathrm{~V} \cdot E_{1 / 2}=0.319 \mathrm{~V}$.

2.5. Peroxidase Probes. Oxidation of $2,2^{\prime}$-azinobis-(3-ethylbenzothiazoline)-6-sulfonic acid (ABTS) with $\mathrm{H}_{2} \mathrm{O}_{2}$ at ca. $\mathrm{pH}$ 6.8 in the presence of complex 7 was tested in the following manner. An aqueous solution of ABTS $(50 \mu \mathrm{L} ; 0.009 \mathrm{M} ; 4.5$ $\left.\times 10^{-7} \mathrm{~mol}\right)$ and a methanolic solution of the complex $(10 \mu \mathrm{L}$; $\left.10^{-3} \mathrm{M} ; 10^{-8} \mathrm{~mol}\right)$ were added to water $(3 \mathrm{~mL})$. The intensity of the UV absorption bands of ABTS started to increase immediately after addition of an aqueous solution of $\mathrm{H}_{2} \mathrm{O}_{2}$ $\left(50 \mu \mathrm{L} ; 10 \mathrm{M} ; 5 \times 10^{-4} \mathrm{~mol}\right)$.

\section{Results and Discussion}

Our synthetic sequence leading to the tetradentate ligand $\mathbf{H}_{2} \mathbf{L}^{1}$ is summarized in Scheme 1. All the precursors and organic compounds were characterised by elemental analysis, ${ }^{1} \mathrm{H}$ NMR and IR spectroscopies, and MS spectrometry.

In the first step, precursor 1 was obtained through Gabriel synthesis [23]. The potassium salt of phthalimide was Nalkylated with a primary alkyl halide such as bromoacetal. The ${ }^{1} \mathrm{H}$ NMR doublet signal at $3.75 \mathrm{ppm}$, corresponding to the methylene group next to the nitrogen atom (R1-N-CH$\left.{ }_{2}-\mathrm{R} 2\right)$, confirmed the formation of the phthalimido-acetal. Figure 2 shows the ${ }^{1} \mathrm{H}$ NMR spectrum for $\mathbf{1}$ and for other organic compounds of the synthetic route $(2,4$, and the final ligand $\mathrm{H}_{2} \mathrm{~L}^{\mathrm{I}}$ ).

Upon workup by acidic hydrolysis with aqueous hydrochloric acid, phthalimidoacetaldehyde 2 was liberated 


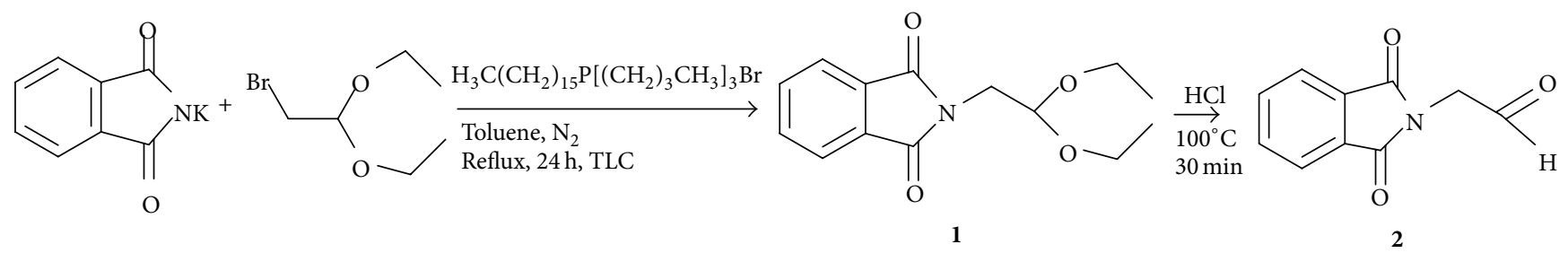<smiles>CNCc1cc(Br)ccc1O</smiles>

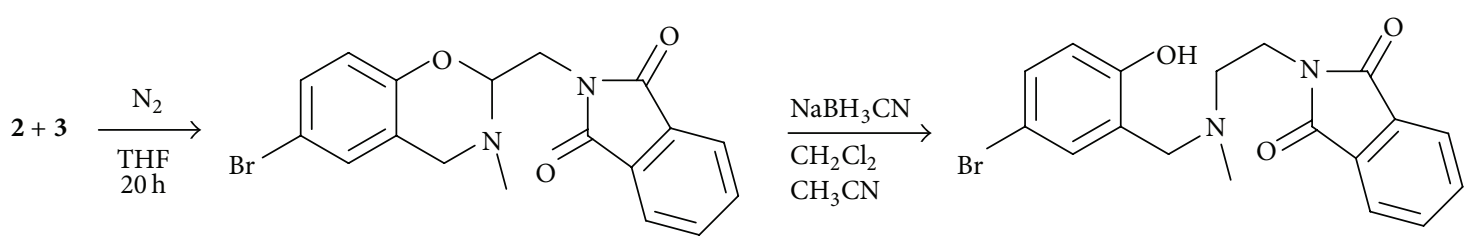

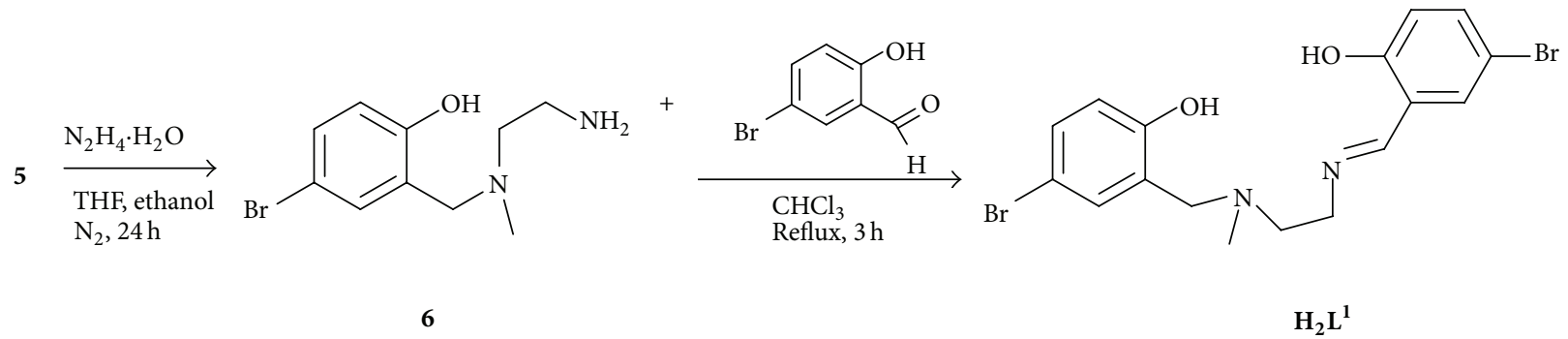

SCHEME 1: Synthetic route to obtain $\mathbf{H}_{2} \mathbf{L}^{\mathbf{1}}$.

[24]. A singlet signal in ${ }^{1} \mathrm{H}$ NMR at $9.6 \mathrm{ppm}$ was assigned to the aldehyde proton (see Figure 2).

For the further course of the synthesis, 4-bromo-salicylaldehyde reacted with methylamine in the presence of a reducing agent such as sodium borohydride [25]. This led to formation of primary amine 3 . The salicylamine was identified by the broad signal at about 4.8-4.2 ppm of the amine proton and also by the singlet at $3.8 \mathrm{ppm}$ corresponding to the protons of the methylene group.

In a fourth step, aminophenol $\mathbf{3}$ was condensed with phthalimidoacetaldehyde 2 , affording benzoxazine 4 . The ${ }^{1} \mathrm{H}$ NMR triplet at $5.1 \mathrm{ppm}$ was characterised as the signal from the proton of the carbon between $\mathrm{N}$ and $\mathrm{O}$ atoms (see Figure 2). The absence in 4 of the IR band at about $2600 \mathrm{~cm}^{-1}$ corresponding to the phenolic and aminic vibrational modes (showed in $\mathbf{2}$ and 3 ) also confirmed the progress of the reaction.

Reductive cleavage of the acetalic $\mathrm{C}-\mathrm{O}$ bond of $\mathbf{4}$ using sodium cyanoborohydride gave N-phthaloyl-protected ethylene diamine 5. The benzoxacine signals disappeared in the ${ }^{1} \mathrm{H}$ NMR spectrum, and the triplets at $3.8 \mathrm{ppm}$ and $2.7 \mathrm{ppm}$ from the methylene chain formed [26]. Deprotection of $\mathbf{5}$ by hydrazinolysis proceeded smoothly, showing the disappearance of the phthalimide signals in ${ }^{1} \mathrm{H}$ NMR and the formation of a new broad signal at 4.1-3.7 ppm from the amine protons [27].

Primary amine 6 was finally condensed with 4-bromosalicylaldehyde, affording the Schiff base $\mathbf{H}_{2} \mathbf{L}^{\mathbf{1}}((E)$-4-bromo2-(((2-((5-bromo-2-hydroxybenzyl) (methyl)amino)ethyl)imino)methyl)phenol). The imine group from $\mathbf{H}_{2} \mathbf{L}^{1}$ is identified by the singlet peak at $8.12 \mathrm{ppm}$ (see ${ }^{1} \mathrm{H}$ NMR in Figure 2) and also by the strong IR band at $1634 \mathrm{~cm}^{-1}$. Other ${ }^{1} \mathrm{H}$ NMR signals, elemental analysis, and ES spectrometry confirm the formation and purity of the $\mathbf{H}_{2} \mathbf{L}^{1}$ amine-imine ligand.

The reaction of $\mathbf{H}_{2} \mathbf{L}^{\mathbf{1}}$ with a manganese plate in an electrochemical cell yields complex 7 with formula $\left[\mathrm{MnL}^{1}\left(\mathrm{OH}_{2}\right)_{2}\right] \cdot \mathrm{H}_{2} \mathrm{O}$ [28]. The electrochemical efficiency of the cell, around $0.5 \mathrm{~mol} \mathrm{~F}^{-1}$, is in accordance with the following mechanism of the reaction:

$$
\begin{gathered}
\text { Cathode: } \mathrm{H}_{2} \mathrm{~L}+2 \mathrm{e}^{-} \longrightarrow \mathrm{H}_{2}(\mathrm{~g})+\mathrm{L}^{2-} \\
\text { Anode: } \mathrm{L}^{2-}+\mathrm{Mn} \longrightarrow \mathrm{MnL}+2 \mathrm{e}^{-}
\end{gathered}
$$

This synthetic procedure allowed us to obtain the neutral complex with high purity and in very good yield. Complex 7 seems to be stable in air and thermally stable, melting above 

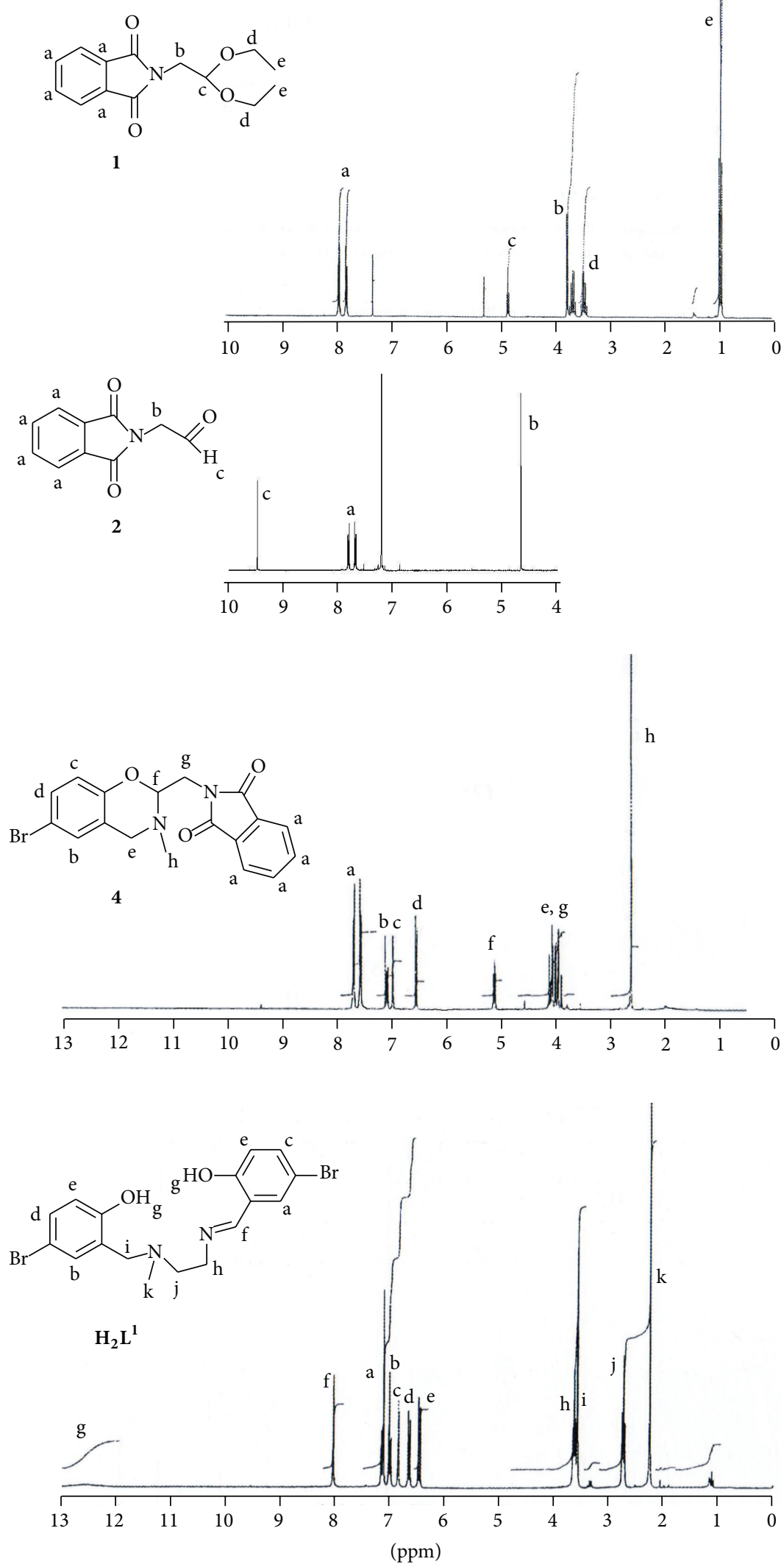

FIGURE 2: ${ }^{1} \mathrm{H}$ NMR spectra and assignments for $\mathbf{1}, \mathbf{2}, \mathbf{3}$, and the ligand $\mathbf{H}_{2} \mathbf{L}^{1}$. 
TABLE 1: Magnetic susceptibility and magnetic moment for 7 at different applied field strengths.

\begin{tabular}{lcc}
\hline Field $(\mathrm{G})$ & $\chi($ uem $/ \mathrm{g})$ & $\mu$ (B. M.) \\
\hline 4696 & 0.3260 & 5.83 \\
5017 & 0.3373 & 5.94 \\
5251 & 0.3464 & 6.19 \\
5486 & 0.3555 & 6.33 \\
5718 & 0.3579 & 6.40 \\
5952 & 0.3637 & 6.51 \\
\hline
\end{tabular}

$300^{\circ} \mathrm{C}$ without decomposition. The complex is insoluble or sparingly soluble in water and common organic solvents, but soluble in polar coordinating solvents such as DMF, DMSO, and pyridine.

The IR spectrum of 7 shows a strong band at $1627 \mathrm{~cm}^{-1}$ attributable to $\nu(\mathrm{C}=\mathrm{N})$. This band appears $7 \mathrm{~cm}^{-1}$ shifted to lower frequency with respect to the free ligand. Moreover, $v(\mathrm{C}-\mathrm{O})$ band is also shifted $3 \mathrm{~cm}^{-1}$ to higher frequency with respect to the free ligand. This behaviour is compatible with the participation of both imine nitrogen and phenolic oxygen atoms in the coordination to the manganese ion, illustrating the dianionic and tetradentate character of this ligand in the complex [29].

The FAB mass spectra show a peak due to the fragment $[\mathrm{MnL}]^{+}$, which thus further corroborate coordination of the ligand to the metal centre. The conductivity value $(9 \mu \mathrm{S})$ suggests the nonionogenous nature for 7 [30].

Magnetic measurements were performed at room temperature for 7 with diamagnetic corrections. The magnetic moment, $\mu=5.94 \mathrm{~B}$. M., is close to those expected for magnetically dilute $\mathrm{Mn}(\mathrm{II})$ ions, confirming the oxidation state II for the central atom and, therefore, confirming the notion that the ligand acts as dianion. The study of the magnetic behaviour at different applied field strengths (Table 1) confirms the values expected for magnetically dilute $\mathrm{Mn}(\mathrm{II})$ ions. Thus, magnetic data suggest the presence of manganese(II) ion in an octahedral environment with little or no interaction between neighbouring metal centres.

Cyclic voltammogram of 7 was measured in dimethylformamide (DMF) over a potential range from +1.00 to $-1.00 \mathrm{~V}$. In DMF solution, the complex exhibits a quasireversible one-electron reduction-oxidation wave, which at slow scan rates of about $0.02 \mathrm{~V} \mathrm{~s}^{-1}$ is reversible (Figure 3; $\left.E_{\text {ox }}=0.488 \mathrm{~V} ; E_{\text {red }}=0.150 \mathrm{~V}\right)$. Nevertheless, the peakto-peak separation $(0.338 \mathrm{~V})$ is slightly longer than in other series of manganese(II) complexes derived from tetradentate Schiff base ligands $[12,13]$, highlighting a poorer reversible character for the present complex.

3.1. Peroxidase Studies. ABTS (diammonium salt of 2,2-azinobis-(3-ethylbenzothiazoline)-6-sulfonic acid) is a colourless water-soluble compound used for clinical peroxidase assays because of its excellent characteristics [31-33]. The peroxidase-like activity of 7 was followed by the oxidation of the ABTS at $\mathrm{pH}$ 6.8. ABTS is colourless and it reacts readily

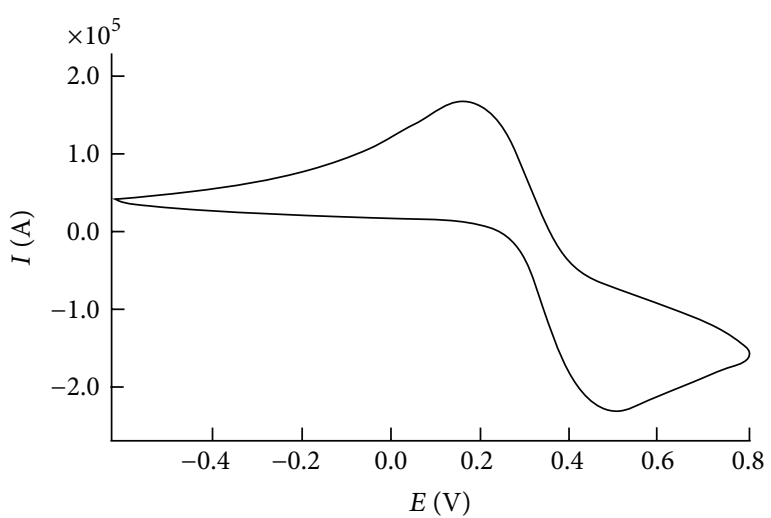

FIgURE 3: Cyclic voltammogram for 7 at scan rate of $0.02 \mathrm{~V} \mathrm{~s}^{-1}$.

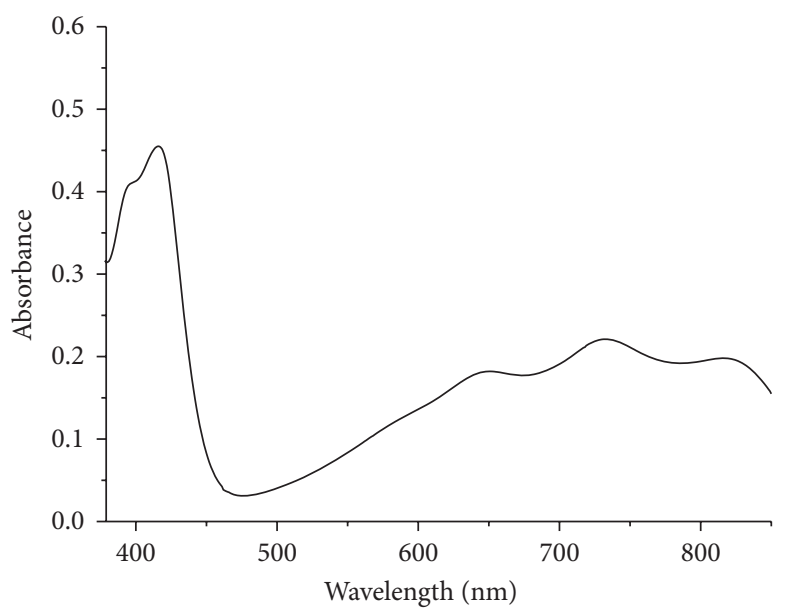

FIGURE 4: UV-Vis absorption spectrum of ABTS $+\mathrm{H}_{2} \mathrm{O}_{2}+7$, recorded $10 \mathrm{~min}$ after mixing the solution.

with hydrogen peroxide in the presence of a peroxidase catalyst to yield a stable green coloured radical cation which absorbs light at 415, 650,735, and $815 \mathrm{~nm}$ [34].

The reaction of ABTS with $\mathrm{H}_{2} \mathrm{O}_{2}$ in the presence of 7 (complex concentration: $3.310^{-6} \mathrm{M}$ ) generates $\mathrm{ABTS}^{\bullet+}$. A reduction of one mole of $\mathrm{H}_{2} \mathrm{O}_{2}$ requires two moles of ABTS, according to the mechanism

$$
2 \mathrm{ABTS}+\mathrm{H}_{2} \mathrm{O}_{2} \stackrel{\text { Mn-SB Complex }}{\longrightarrow} 2 \mathrm{ABTS}^{\bullet+}+2 \mathrm{H}_{2} \mathrm{O}
$$

The oxidised form, $\mathrm{ABTS}^{\circ+}$, can be clearly identified by its characteristic absorption bands (Figure 4) and measured quantitatively at $\lambda=650 \mathrm{~nm}$, since $\varepsilon=12000 \mathrm{M}^{-1} \mathrm{~cm}^{-1}$ has been determined. Further oxidation to the corresponding dication was not observed. In the absence of the complex, a solution of ABTS and $\mathrm{H}_{2} \mathrm{O}_{2}$ is stable for several hours without showing any formation of $\mathrm{ABTS}^{\circ}$.

The rate of formation of $\mathrm{ABTS}^{\bullet+}$ of about $11 \%$ shows a significant capacity of hydrogen peroxide decomposition by 7. The activity is comparable to that of a previous series of Mn-Schiff base complexes, reported by us [12, 13], but is much higher than an earlier Mn-Schiff base series with high symmetrical octahedral geometries [35]. 
With regard to the peroxidase activity, two of the most important questions that are of concern are (a) the rate of reversibility of the $\mathrm{Mn}(\mathrm{II}) / \mathrm{Mn}(\mathrm{III})$ redox potentials and (b) the ease of coordination of the substrate molecule to the manganese ion. The peak-to-peak separation of $0.338 \mathrm{~V}$ for the oxidation-reduction wave of $\mathbf{7}$ is slightly longer than in other series of efficient peroxidase mimics, and even longer than in other series of Mn(II) inactive complexes. Despite this limited reversible character, the behaviour of complex 7 as peroxidase mimic may be attributable to its capacity to coordinate the substrate molecule. Our strategy in the design of the ligand $\mathbf{H}_{2} \mathbf{L}^{1}$ sought adequate conformations and flexibility to coordinate metal ions in a way that two adjacent positions of the coordination sphere may be vacant or filled with labile ligands. The different hybridization mode for the amino $\left(\mathrm{sp}^{3}\right)$ and imino $\left(\mathrm{sp}^{2}\right)$ groups may favour the tetracoordination of the organic ligand outside from the equatorial plane of the metal ion. In this case, two of the cis positions of a hypothetical first coordination sphere would not be occupied by the ligand and, subsequently, these two cis positions would be able to coordinate a suitable substrate molecule for catalysis.

On the other hand, the reversible character of the redox potentials for this new type of complexes may be increased using different electron donor/withdrawing substituents on the phenyl rings of the ligand [36-38]. Thus, more efficient peroxidase mimics would be achieved using this new type of asymmetric ligands, containing both amino and imino groups, by employing appropriate substituents on the phenyl rings.

\section{Conclusions}

Complex 7, which behaves as a manganese(II) peroxidase mimic, incorporates a new asymmetric ligand $\mathbf{H}_{2} \mathbf{L}^{1}$ containing both amino and imino groups. The seven-step synthetic route for $\mathbf{H}_{2} \mathbf{L}^{1}$ afforded successfully the desired asymmetric product with a reasonable yield. This synthetic strategy may be used to obtain a new family of organic ligands suitable for coordination of different metal ions. The variety of this novel family of ligands may be envisioned by the chance of replacing the methylamine used in the third step of the synthetic route by different amines or amino acids. The peroxidase activity of this type of complexes would be enhanced by employing electron donor/withdrawing substituents on the phenyl rings to get complexes with better reversible character for the electrochemical processes.

\section{Conflict of Interests}

The authors declare that there is no conflict of interests regarding the publication of this paper.

\section{Acknowledgment}

Financial support from the Xunta de Galicia (GRC2014/025; MetalBIO Network R2014/004) is acknowledged.

\section{References}

[1] B. Halliwell and J. M. C. Gutteridge, Free Radicals in Biology and Medicine, Oxford University Press, Oxford, UK, 4th edition, 2007.

[2] V. Calabrese, C. Cornelius, C. Mancuso et al., "Cellular stress response: a novel target for chemoprevention and nutritional neuroprotection in aging, neurodegenerative disorders and longevity," Neurochemical Research, vol. 33, no. 12, pp. 24442471, 2008.

[3] M. M. Moschos, E. Nitoda, I. P. Chatziralli, and C. A. Demopoulos, "Age-related macular degeneration: pathogenesis, genetic background, and the role of nutritional supplements," Journal of Chemistry, vol. 2014, Article ID 317536, 9 pages, 2014.

[4] B. Palenik, B. Brahamsha, F. W. Larimer et al., "The genome of a motile marine Synechococcus," Nature, vol. 424, no. 6952, pp. 1037-1042, 2003.

[5] A. J. Wu, J. E. Penner-Hahn, and V. L. Pecoraro, "Structural, spectroscopic, and reactivity models for the manganese catalases," Chemical Reviews, vol. 104, no. 2, pp. 903-938, 2004.

[6] S. R. Doctrow, M. Liesa, S. Melov, O. S. Shirihai, and P. Tofilon, "Salen Mn complexes are superoxide dismutase and catalase mimetics that protect the mitocondria," Current Inorganic Chemistry, vol. 2, pp. 325-334, 2012.

[7] N. Gao, H. Li, Q. Li, J. Liu, and G. Luo, "Synthesis and kinetic evaluation of a trifunctional enzyme mimic with a dimanganese active centre," Journal of Inorganic Biochemistry, vol. 105, no. 2, pp. 283-288, 2011.

[8] T. R. Simmons, G. Berggren, M. Bacchi, M. Fontecave, and V. Artero, "Mimicking hydrogenases: from biomimetics to artificial enzymes," Coordination Chemistry Reviews, vol. 270271, pp. 127-150, 2014.

[9] S. Signorella and C. Hureau, "Bioinspired functional mimics of the manganese catalases," Coordination Chemistry Reviews, vol. 256, no. 11-12, pp. 1229-1245, 2012.

[10] D. Bani and A. Bencini, "Developing ROS scavenging agents for pharmacological purposes: recent advances in design of manganese-based complexes with anti-inflammatory and antinociceptive activity," Current Medicinal Chemistry, vol. 19, no. 26, pp. 4431-4444, 2012.

[11] I. Batinić-Haberle, J. S. Rebouças, and I. Spasojević, "Superoxide dismutase mimics: chemistry, pharmacology, and therapeutic potential," Antioxidants and Redox Signaling, vol. 13, no. 6, pp. 877-918, 2010.

[12] M. R. Bermejo, M. I. Fernández, A. M. González-Noya et al., "Novel peroxidase mimics: $\mu$-aqua manganese-Schiff base dimers," Journal of Inorganic Biochemistry, vol. 100, pp. 14701478,2006

[13] A. Vázquez-Fernández, M. R. Bermejo, M. I. FernándezGarcía, G. González-Riopedre, M. J. Rodríguez-Doutón, and M. Maneiro, "Influence of the geometry around the manganese ions on the peroxidase and the catalase activities of $\mathrm{Mn}$ (III)Schiff base complexes," Journal of Inorganic Biochemistry, vol. 105, pp. 1538-1547, 2011.

[14] G. González-Riopedre, M. I. Fernández-García, A. M. González-Noya, M. Á. Vázquez-Fernández, M. R. Bermejo, and M. Maneiro, "Manganese-Schiff base complexes as catalysts for water photolysis," Physical Chemistry Chemical Physics, vol. 13, no. 40, pp. 18069-18077, 2011.

[15] G. González-Riopedre, M. R. Bermejo, M. I. Fernández-García et al., "Alkali-metal-ion-directed self-assembly of redox-active 
manganese(III) supramolecular boxes," Inorganic Chemistry, vol. 54, no. 6, pp. 2512-2521, 2015.

[16] R. Noyori and S. Hashiguchi, "Asymmetric transfer hydrogenation catalyzed by chiral ruthenium complexes," Accounts of Chemical Research, vol. 30, no. 2, pp. 97-102, 1997.

[17] Y. Rondelez, M.-N. Rager, A. Duprat, and O. Reinaud, "Calix[6]arene-based cuprous 'funnel complexes': a mimic for the substrate access channel to metalloenzyme active sites," Journal of the American Chemical Society, vol. 124, no. 7, pp. 1334-1340, 2002.

[18] G. Zassinovich, G. Mestroni, and S. Gladiali, "Asymmetric hydrogen transfer reactions promoted by homogeneous transition metal catalysts," Chemical Reviews, vol. 92, no. 5, pp. 10511069, 1992.

[19] V. Alexander, "Design and synthesis of macrocyclic ligands and their complexes of lanthanides and actinides," Chemical Reviews, vol. 95, no. 2, pp. 273-342, 1995.

[20] G. Kumar, R. Johari, and S. Devi, "Synthesis, physical characterization of $\mathrm{M}(\mathrm{III})$ transition metal complexes derived from thiodihydrazide and 5-tert-butyl-2-hydroxy-3-(3-phenylpent3-yl) benzaldehyde," E-Journal of Chemistry, vol. 9, no. 4, pp. 2119-2127, 2012.

[21] E. López-Torres and M. A. Mendiola, "Mercury complexes with the ligand benzaldehyde-N(4),N(4)-dimethylthiosemicarbazone," Inorganica Chimica Acta, vol. 363, no. 6, pp. 1275-1283, 2010.

[22] R. Pedrido, M. J. Romero, M. R. Bermejo et al., "Influence of the metal size in the structure of the complexes derived from a pentadentate $\left[\mathrm{N}_{3} \mathrm{O}_{2}\right]$ hydrazone," Dalton Transactions, no. 44, pp. 5304-5314, 2006.

[23] J. C. Sheehan and W. A. Bolhofer, "An improved procedure for the condensation of potassium phthalimide with organic halides," Journal of the American Chemical Society, vol. 72, no. 6, pp. 2786-2788, 1950.

[24] K. Jarowicki and P. Kocienski, "Protecting groups," Journal of Chemical Society. Perkin Transactions, vol. 18, pp. 2109-2135, 2001.

[25] J. F. Hartwig, "Evolution of a fourth generation catalyst for the amination and thioetherification of aryl halides," Accounts of Chemical Research, vol. 41, no. 11, pp. 1534-1544, 2008.

[26] A. Berkessel, M. Bolte, T. Neumann, and L. Seidel, "Synthesis and X-ray crystal structure of the first mononuclear nickel(II) alkane thiolate complex with a mixed (S,N,N,O) ligand field," Chemische Berichte, vol. 129, no. 10, pp. 1183-1189, 1996.

[27] M. S. Gibson and R. W. Bradshaw, "Gabriel synthesis of primary amines," Angewandte Chemie-International Edition, vol. 7, pp. 919-930, 1968.

[28] C. Oldham and D. G. Tuck, "The direct electrochemical synthesis of $\left[\left(\mathrm{C}_{6} \mathrm{H}_{5}\right)_{3} \mathrm{Ph}\right]_{2}\left[\mathrm{CoCl}_{4}\right]$ : an example of the use of anodic oxidation in the preparation of metal ion complexes," Journal of Chemical Education, vol. 59, no. 4, pp. 420-421, 1982.

[29] R. Golbedaghi, S. Salehzadeh, H. R. Khavasi, and A. G. Blackman, "Mn(II) complexes of three [2+2] macrocyclic Schiff base ligands. Synthesis and X-ray crystal structure of the first binuclear-di(binuclear) cocrystal," Polyhedron, vol. 68, pp. 151156, 2014.

[30] W. J. Geary, "The use of conductivity measurements in organic solvents for the characterisation of coordination compounds," Coordination Chemistry Reviews, vol. 7, no. 1, pp. 81-122, 1971.
[31] E. S. Ryabova, P. Rydberg, M. Kolberg et al., "A comparative reactivity study of microperoxidases based on hemin, mesohemin and deuterohemin," Journal of Inorganic Biochemistry, vol. 99, no. 3, pp. 852-863, 2005.

[32] C. L. Hunter, R. Maurus, M. R. Mauk et al., "Introduction and characterization of a functionally linked metal ion binding site at the exposed heme edge of myoglobin," Proceedings of the National Academy of Sciences of the United States of America, vol. 100, no. 7, pp. 3647-3652, 2003.

[33] M. Zampakou, V. Tangoulis, C. P. Raptopoulou, V. Psycharis, A. N. Papadopoulos, and G. Psomas, "Structurally diverse manganese(II)-diclofenac complexes showing enhanced antioxidant activity and affinity to serum albumins in comparison to sodium diclofenaco," European Journal of Inorganic Chemistry, vol. 2015, no. 13, pp. 2285-2294, 2015.

[34] M. F. Zipplies, W. A. Lee, and T. C. Bruice, "Influence of hydrogen ion activity and general acid-base catalysis on the rate of decomposition of hydrogen peroxide by a novel nonaggregating water-soluble iron(III) tetraphenylporphyrin derivative," Journal of the American Chemical Society, vol. 108, no. 15, pp. 4433-4445, 1986.

[35] M. Maneiro, M. R. Bermejo, A. Sousa et al., "Synthesis and structural characterisation of new manganese(II) and (III) complexes. Study of their photolytic and catalase activity and X-ray crystal structure of $[\mathrm{Mn}(3-\mathrm{OMe}, 5-\mathrm{Br}-$ salpn $\left.(\mathrm{EtOH})\left(\mathrm{H}_{2} \mathrm{O}\right)\right] \mathrm{ClO}_{4}$," Polyhedron, vol. 19, no. 1, pp. 47-54, 2000.

[36] K. Mitra, S. Biswas, C. R. Lucas, and B. Adhikary, "Manganese(III) complexes of $\mathrm{N}_{2} \mathrm{O}_{2}$ donor 5-bromosalicylideneimine ligands: combined effects of electron withdrawing substituents and chelate ring size variations on electrochemical properties," Inorganica Chimica Acta, vol. 359, no. 7, pp. 19972003, 2006.

[37] S. Naskar, S. Naskar, R. J. Butcher, M. Corbella, A. Espinosa Ferao, and S. K. Chattopadhyay, "Synthesis, X-ray crystal structures, and spectroscopic, electrochemical, and theoretical studies of $\mathrm{Mn}^{\mathrm{III}}$ complexes of pyridoxal schiff bases with two diamines," European Journal of Inorganic Chemistry, no. 18, pp. 3249-3260, 2013.

[38] C. Palopoli, C. Duhayon, J.-P. Tuchagues, and S. Signorella, "Synthesis, characterization, and reactivity studies of a watersoluble bis(alkoxo)(carboxylato)-bridged diMnIII complex modeling the active site in catalase," Dalton Transactions, vol. 43, no. 45, pp. 17145-17155, 2014. 

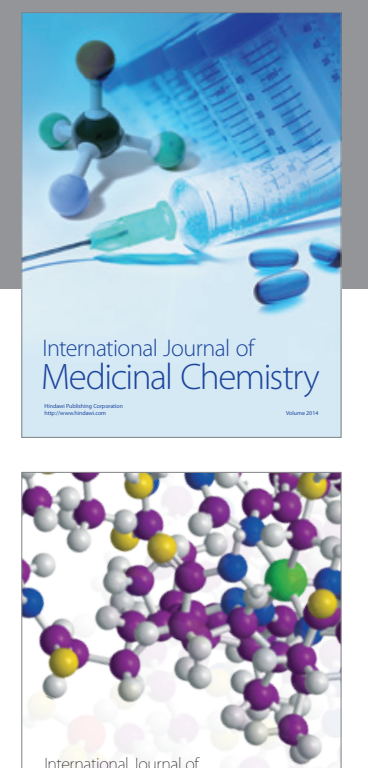

\section{Carbohydrate} Chemistry

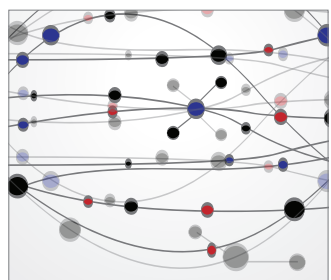

The Scientific World Journal
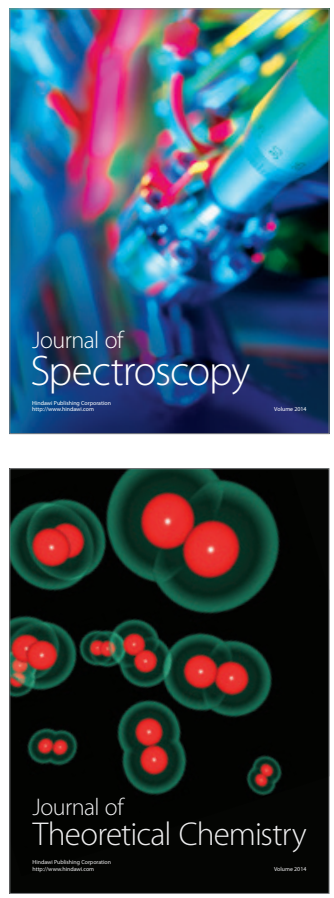
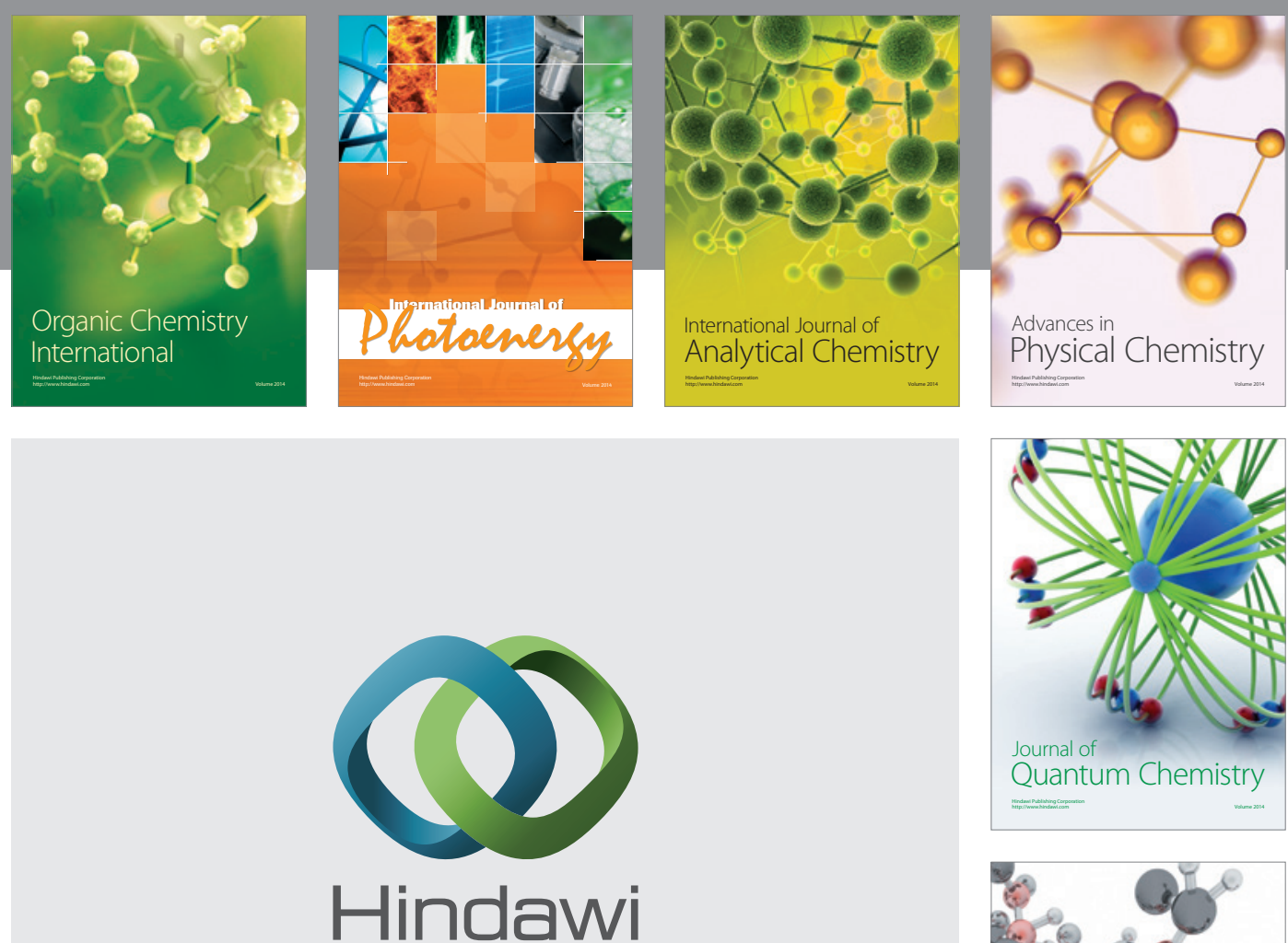

Submit your manuscripts at

http://www.hindawi.com

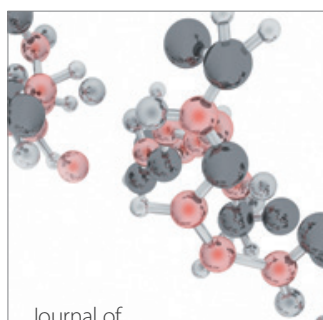

Analytical Methods

in Chemistry

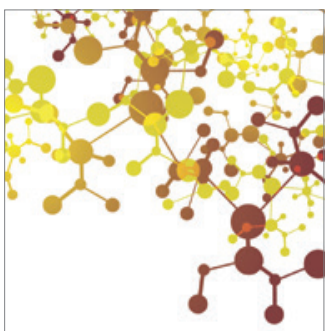

Journal of

Applied Chemistry

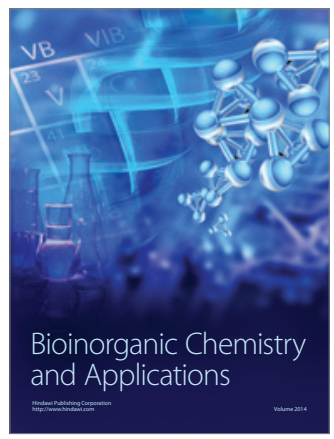

Inorganic Chemistry
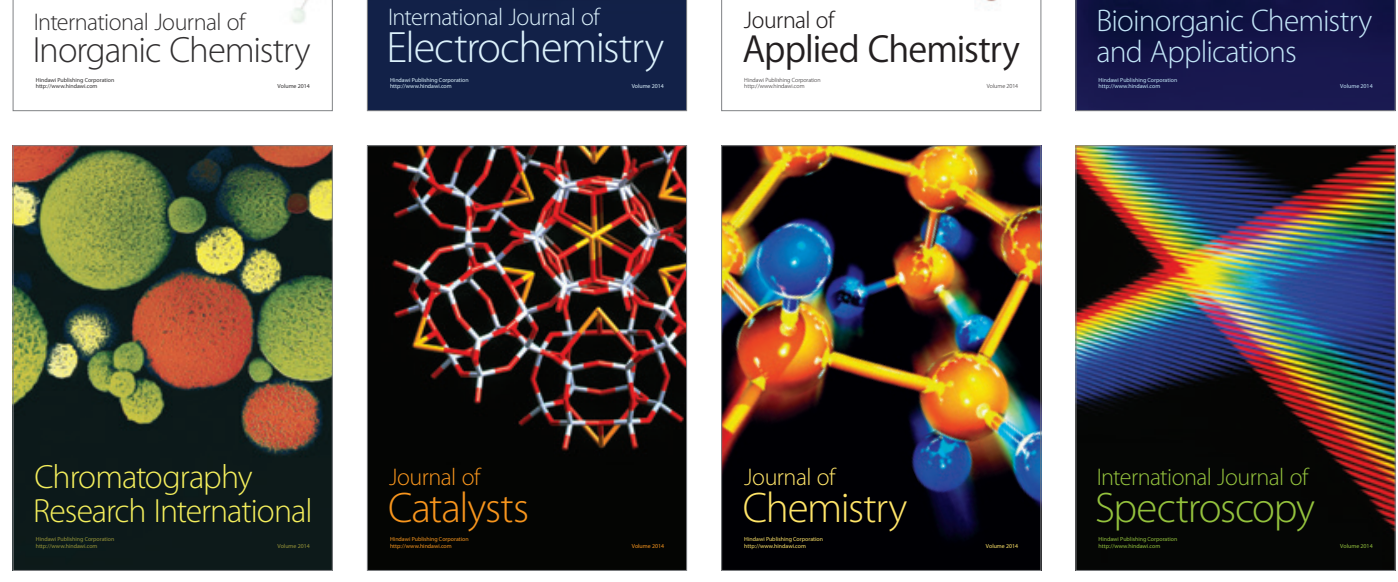